\title{
Agroclimatic risk zoning for guava (Psidium guajava L.) in Paraná river basin 3
}

\section{Nathan Felipe da Silva Caldana ${ }^{1}$, Pablo Ricardo Nitsche ${ }^{2}$, Alan Carlos Martelócio ${ }^{2}$, Luiz Gustavo Batista Ferreira², Paulo Henrique Caramori², Jorge Alberto Martins ${ }^{1}$}

\author{
${ }^{1}$ Universidade Tecnológica Federal do Paraná, Campus Londrina, Londrina, Paraná, Brasil. E-mail: nathancaldana@ gmail.com; \\ jmartins@utfpr.edu.br; \\ ${ }^{2}$ Instituto Agronômico do Paraná, Londrina, Paraná, Brasil. E-mail: pablo@iapar.br, amartelocio@agronomo.eng.br, \\ luiz.gustavo@agronomo.eng.br, pcaramori@gmail.com
}

Received: 17/10/2019; Accepted: 29/04/2020.

\begin{abstract}
Fruticulture constitutes an important sector of the Brazilian agricultural industry. Despite technological and scientific advances, climate is still the most important variable defining crop productivity. Because of this, agroclimatic zoning should be one of the first factors to consider when starting to plant a particular crop. The objective of this work was to conduct climate risk zoning for guava (Psidium guajava L.) in Paraná river basin 3, Paraná, Brazil, using meteorological data from 43 stations collected between 1976 and 2018. The climate risk analysis was based on the climatic factors that impact the species, such as rainfall, annual water deficit, average annual temperature, coldest month temperature, and risk of frost. The findings of this study suggest that the basin has areas with a low climate risk for guava cultivation. Precipitation and water balance were sufficient under all tested scenarios. The most limiting factor for production was frost, but with risk only present during the first years of cultivation. Despite this, planting restrictions were only predicted to occur in the far west portion of the basin. Agricultural techniques that reduce the risk of frost and avoiding areas with greater frost incidences are the two most important aspects to consider to ensure greater success for guava in the region.
\end{abstract}

Keywords: climate aptitude; climate variability; agricultural planning.

\section{Zoneamento de risco agroclimático da goiabeira (Psidium guajava L.) na bacia do rio Paraná 3}

\section{RESUMO}

A fruticultura é um segmento de destaque da agricultura brasileira. Apesar dos recentes avanços tecnológicos e científicos, o clima é ainda a variável mais importante na produtividade agrícola. Nesse contexto, o zoneamento agroclimático deve ser uma das primeiras informações a serem consideradas ao iniciar o cultivo de determinada cultura. Dessa forma, objetivou-se neste trabalho realizar o zoneamento de risco climático para a goiabeira (Psidium guajava L.) na bacia do Rio Paraná 3, estado do Paraná. Para isso foram utilizados dados meteorológicos de 43 estações com recorte temporal de 1976-2018. A análise do risco climático foi pautada nas exigências climáticas da espécie, sendo estas, precipitação, deficiência hídrica anual, temperatura média anual e do mês mais frio e o risco de geada. A bacia possui regiões com baixo risco climático para a cultura da goiabeira. A precipitação e o balanço hídrico apresentaram valores suficientes em todos os cenários testados. O fator mais limitante para a produção é a geada, porém, como é um risco apenas nos anos iniciais do cultivar, houve apenas restrição para o plantio na porção extremo oeste da bacia. Técnicas de manejo podem ser tomadas para evitar o risco de geada e evitar áreas com maior incidência do fenômeno pode garantir maior sucesso no cultivo de goiaba da região.

Palavras-chave: aptidão climática; variabilidade climática; planejamento agrícola 


\section{Introduction}

Fruticulture is an agricultural activity that contributes significantly to national economic development in Brazil. Fruticulture, as an agriculture sector, is enmeshed in the risks and uncertainties that meteorological and climatic elements pose, causing variability in production and necessitating different in fruit growing management practices (Mustafa et al., 2018; Oliveira et al., 2018; Somboonsuke et al., 2018; Tayt'sohn et al., 2018; Agovino et al., 2019).

Understanding the specific characteristics of each climate and soil could help producers to choose appropriate crops and management techniques in order to achieve higher incomes and lower losses. Among the agrometeorological information employed in agricultural planning, agroclimatic risk zoning is the most wellknown to apply in agriculture. Caramori et al., 2008; Ricce et al., 2014; Santi et al., 2017).

The guava tree (Psidium guajava L.) is a perennial tree belonging to the Mirtaceae family. It is a rustic and native plant from the tropics, adapts easily to environmental variation, and can develop in both tropical and subtropical climates. The tree grows to a height of 3 to 10 meters and, in tropical regions, guava can flower and fruit continuously throughout the year (Medina et al., 1991). In south Brazil, the state of Rio Grande do Sul plays host to the largest cultivated area of guava tree production (Almeida et al., 2014).

The state of Paraná, south Brazil, produces negligible quantities of guava when compared to other fruits. In 2017, the state recorded 7 tons of guava produced over an area of approximately $670 \mathrm{ha}^{-1}$ (IPARDES, 2019). Several studies around the world, aim of improving guava management techniques and production (Salazar et al., 2006; Rezende et al., 2015; Abdel-Rahim and AboElyousr, 2017; Moon et al., 2018; Adhiambo et al., 2019; Blanco et al., 2019). The purpose of the present work was to carry out climatic risk agricultural zoning for guava in Paraná river basin 3, a drainage area on the left bank of the Itaipú reservoir located between the Iguaçu and Piquiri rivers.

\section{Materials and Methods \\ 2.1. Climate Variability}

The hydroclimatic requirements of guava, as well as annual, seasonal, monthly, and daily time series data collected by meteorological stations between 1976 and 2018, were selected for use in the present study. The following meteorological variables were evaluated for guava zoning: annual and coldest month average temperature, annual water deficit, annual average precipitation, and frost occurrences (Sentelhas et al., 1996; Lazzarotto et al., 2005; Sousa et al., 2013; Almeida et al., 2014).

We analyzed 6 meteorological stations from IAPAR (Instituto Agronomico do Paraná; Brazil) provided data from 1976 to 2018; 10 stations of the SIMEPAR (Sistema Meteorológico do Paraná; Brazil) supplied data from 2000 to 2018, and 27 stations belonging to Águas Paraná (Brazil) collected data from 1976 to 2018, as highlighted in Figure 1.



Figure 1. Hypsometry of and station locations in Paraná river basin 3 - adapted and organized by the authors (2019). 
For precipitation analyses, only data from rainfall stations was used, as these could provide a long data series (1976-2018). The spatialization of these data was performed through interpolation, which is an effective method of spatially visualizing climate data. This was done through isohyets and/or spatially filling the values adjusted by regression statistics and using the Inverse Distance Weighted (IDW) spatial interpolation algorithm (Mueller et al., 2004; Lem et al., 2013). Maps were created with aid of QGIS software.

The raw rainfall data were entered into QGIS and were transformed into a raster file with aid of the IDW interpolator. This new file displayed a regular surface adjusted to these point data of interest with a spatial resolution pixel of $1 \mathrm{~km}$ by $1 \mathrm{~km}$. Subsequently, isohyets and their values were inserted to more clearly visualize of areas with similar precipitation and/or insolation levels and to regionalize these areas. The distribution of annual precipitation was also investigated based on the following regional weather stations: Missal (West), Cascavel (South) and Vera Cruz do Oeste (Center), Foz do Iguaçu (South) and Terra Roxa (North).

The Shuttle Radar Topography Mission (SRTM) database was used to correct the influence of topography on temperature at $30 \mathrm{~m}$ resolution. This method was needed to spatialize and regionalize the data to include areas for which there was no accurate temperature data.

Multiple linear regression equations were applied to spatialize the average temperature and frost data measured at the meteorological stations. The following equation was applied: $\mathrm{y}=\mathrm{a}+\mathrm{b}$.lat $+\mathrm{c}$.long $+\mathrm{d}$.alt, where $\mathrm{a}, \mathrm{b}, \mathrm{c}$, and d are regression coefficients, and lat, long, and alt represent latitude, longitudeand altitude, respectively. This mathematic formula was applied over the SRTM file using the ArcGIS v.10.0 geoprocessing software, making it possible to generate maps with a spatial resolution of $30 \mathrm{~m}$.

The method used to calculate the probability of frost was based on the historical minimum temperature series recorded by the meteorological stations. The probabilities of values equal to or lower than $1.0^{\circ} \mathrm{C}$ were calculated, these were adjusted to the following equation: $\mathrm{y}=\mathrm{a}+\mathrm{x}$. lat $+\mathrm{y}$. long $+\mathrm{z}$. alt.

The water balance was obtained using the methods outlined in Thornthwaite and Mather (1955), using an equation containing the values of several meteorological variables in addition to the available soil water capacity proportional to the effective depth of the roots of the analyzed species. The monthly average rainfall data (extracted from the monthly totals of each year) and the monthly average temperature (extracted from the monthly average daily values of each year) were also taken into consideration. Then, the potential evapotranspiration (PET) was calculated, according to the Thornthwaite method. First, the standard potential evapotranspiration (PET, mm/month) was calculated using the following empirical formula:

i) For $0<\mathrm{Tn}<26.5^{\circ} \mathrm{C}$

PET $=16\left(10 \frac{\mathrm{Tn}}{\mathrm{I}}\right)^{\mathrm{a}}$

ii) For $\mathrm{Tn} \geq 26.5{ }^{\circ} \mathrm{C} \mathrm{Tn}^{2}$

PET $=-415,85+32,24 \mathrm{Tn}-43.0 \mathrm{Tn}^{2}$

Where: $\mathrm{Tn}$ - average temperature of month $\mathrm{n}(\mathrm{n}=1$ is January, $\mathrm{n}=2$ is February, etc.), in ${ }^{\circ} \mathrm{C}$, and I - an index that expresses the heat level of the region.

The value of I depends on the annual temperature cycle, integrating the thermal effect of each month, and was calculated using the following formula:

$$
\mathrm{I}=12(0,2 \mathrm{Ta})^{1,514}
$$

The exponent " $\mathrm{a}$ ", as a function of $\mathrm{I}$, is also a regional thermal index, and is calculated by the following expression:

$$
\begin{aligned}
a=0.49239+ & 1.7912 \times 10^{-2} I-7.71 \times 10^{-5} I^{2} \\
+ & 6.75 \times 10^{-7} I^{3}
\end{aligned}
$$

The PET value represents the total monthly evapotranspiration that would occur under the thermal conditions of a standard 30-day month, with each day having a 12-hour photoperiod $(\mathrm{N})$. Therefore, PET should be corrected for $\mathrm{N}$ and the number of days in the month.

$$
C O R=\left(\frac{N}{12}\right)\left(\frac{N D P}{31}\right)
$$

\subsection{Agroclimatic risk zoning}

The risk factors selected for agricultural climate risk zoning were:

a) Annual precipitation: Monthly and annual rainfall data series were collected from 27 meteorological stations. The obtained results were interpolated in a Geographic Information System (GIS) to generate maps, with regionalization of the data performed by the IDW spatial interpolation algorithm. The following rainfall categories were created: high risk - annual precipitation below 700 $\mathrm{mm}$, and low risk - annual precipitation between 1,000 and 2,000 $\mathrm{mm}$ distributed throughout the year (Lazzarotto et al., 2005; Sousa et al., 2013; Almeida et al., 2014).

b) Annual Water Deficiency (AWD) and Monthly Water Deficiency (MWD): AWD was estimated according to the methodology outlined in Thornthwaite and Matter (1955) and was obtained through calculating the normal climatic water balance for the meteorological stations. A value of $80 \mathrm{~mm}$ was used as the available water capacity in the soil due to the fact that the guava root system explores a depth of more than $90 \mathrm{~cm}$ into the soil profile (Bassoi et al., 2002). The results obtained were interpolated in ArcGIS to generate annual water deficit maps. The following categories were determined for water deficiency risk: high risk - AWD greater than $100 \mathrm{~mm}$, and low risk - AWD less than $100 \mathrm{~mm}$ (Lazzarotto et al., 2005; Sousa et al., 2013; Almeida et al., 2014). 
c) Average annual temperature (Ta): Data from an historical series of average temperatures recorded by meteorological stations were used to estimate the average annual temperature. Using the Ta value, regression was applied as a function of latitude, longitude, and altitude for the whole basin. The risk classes defined for Ta were: high risk - below $19^{\circ} \mathrm{C}$, and low risk - above $19^{\circ} \mathrm{C}$ (Sentelhas et al., 1996; Lazzarotto et al., 2005; Sousa et al., 2013; Almeida et al., 2014).

d) Minimum average temperature of the coldest month (Tmf): Data from an historical series of average daily temperatures measured by meteorological stations we used to calculate the July average temperatures. Using these values, a regression equation was adjusted as a function of latitude, longitude, and altitude for the whole basin. The risk classes were defined as: high risk - Tmf below $14{ }^{\circ} \mathrm{C}$, and low risk - Tmf above $14{ }^{\circ} \mathrm{C}$ (Sentelhas et al., 1996; Lazzarotto et al., 2005; Sousa et al., 2013; Almeida et al., 2014).

e) Frost risk: Data from an historical series of minimum temperature recorded at 13 meteorological stations were used, and measurements of $2{ }^{\circ} \mathrm{C}$ or less were isolated to calculate frost risk. The annual probabilities of occurrence were calculated and correlated with altitude and latitude, obtaining a regression equation for the risk of frost. Using adjusted regression, values greater than $40 \%$ were categorized as high risk (Sentelhas et al., 1996; Almeida et al., 2014).

To create thematic maps and the final zoning map in ArcGIS, the numerical values from the weather stations were transformed into points, according to the geographical coordinates of the stations. After this, the edaphoclimatic requirements of the guava species were used to spatialize the data. Delimitations based on representative bands of the climate requirements of guava were created. The station values were replaced by " 1 . Apt" or "2. Restricted" according to the physiological values of each meteorological variable analyzed. The next step was to combine the matrix images. Each pixel was assigned a value of "1" or " 2 ", indicating 'Apt' or 'Restricted', respectively. If the combination for a point was filled only with values of " 1 ", the region was classified as fit for guava production. If the combination contained one value of " 2 ", the region was restricted by a given variable. If two or more " 2 " values were present, the location was classified as unfit.

The standardization of the pixels by classification was performed by dissolving the vector classes. In this way, the agroclimatic zoning classes were grouped, thus creating a regionalization of suitability for the species. The final agroclimatic zoning map provides an estimate of the representative number of areas in each risk class, thus indicating whether the site is suitable or not.

\section{Results and Discussion}

High average annual rainfall was observed throughout Paraná river basin 3 (Figure 2). In terms of rainfall, none of the basin regions constituted a production risk, with all at a level of $1000 \mathrm{~mm}$ annually. The lowest average annual rainfall was $1,550 \mathrm{~mm}$, which was found at the at the northern edge of the basin.
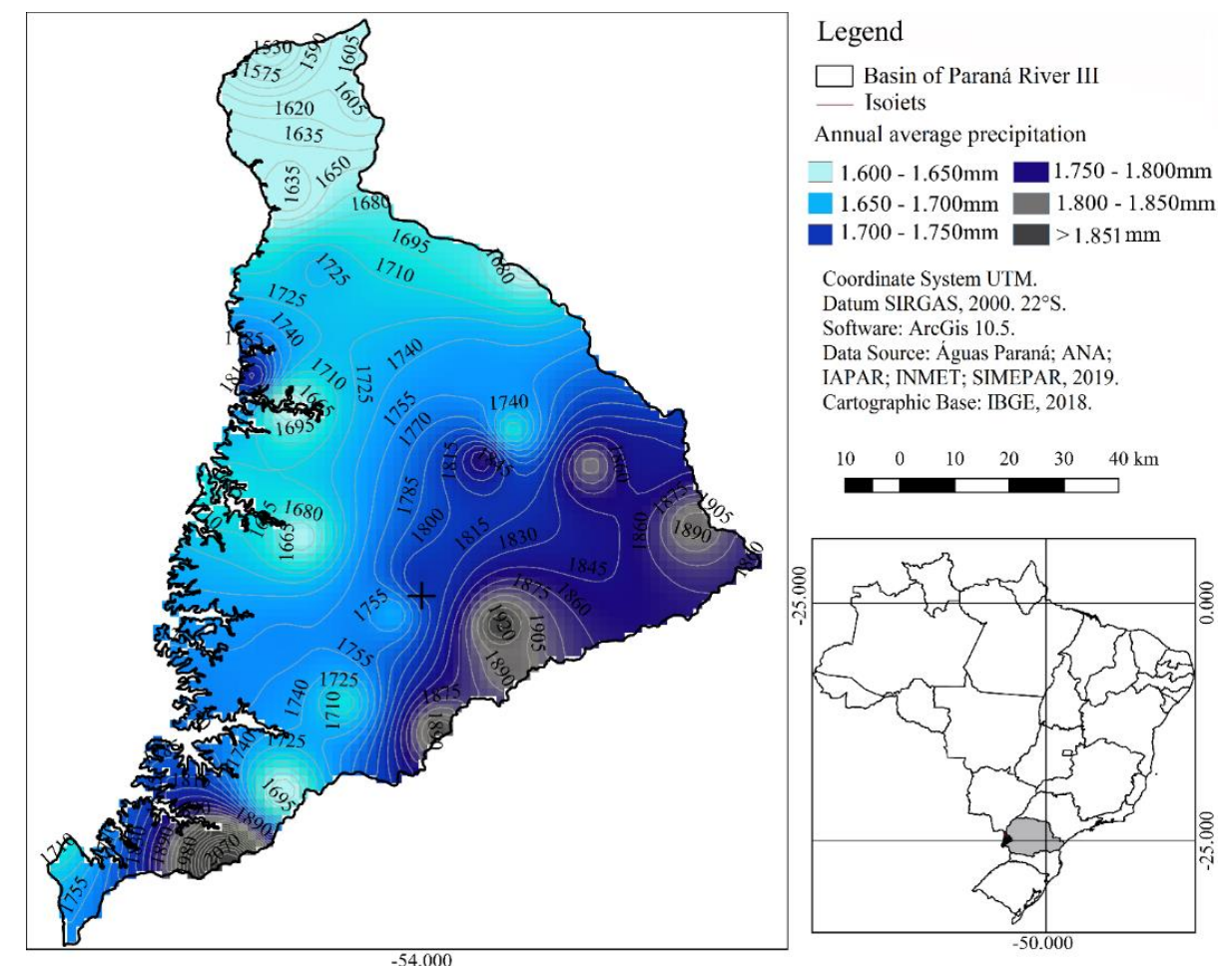

Figure 2. Average annual rainfall in Paraná river basin 3 - adapted and organized by the authors (2019). 
The need for water was assessed through the water balance (Figure 3). Due to the fact that guava is a perennial tree-sized plant with a deep root system, it can tolerate short periods of drought without any losses in production. However, water deficiency during the fruiting period causes a reduction in production. This suggests that using irrigation may achieve high levels of commercial profitability, especially in regions with annual rainfall of less than $700 \mathrm{~mm}$ per year (Medina, 1988).

Here, the municipalities of Cascavel, São Miguel do Iguaçu, and Toledo experienced no water deficiency in any month due to water balance, while the municipality of Assis Chateabreand experienced a water deficit of 1.2 $\mathrm{mm}$ in March. Foz Iguaçu and Guaíra presented more sever water deficits in March of 22 and $37 \mathrm{~mm}$, respectively. The replacement in Guaíra is completed only in May. For water deficit risk assessed at an accumulated $80 \mathrm{~mm}$ per year, no season presented a risk for guava crops. In Guaíra, for example, which experienced a greater water deficit than other municipalities, the annual accumulated water deficit was $56 \mathrm{~mm}$ (Figure 3). Because the species has deep roots, the plant can extract water from deeper soils (Bassoi et al., 2002). The data show a less favorable water balance from January to April due to high temperatures and increased evapotranspiration. However, the AWD in these months was not limiting for the establishment of guava in the region, and only the planting period should be adjusted to avoid droughts periods.

For guava trees in southern Brazil, the most severe climate risk is low temperatures whilst the plants form flower and fruit tissues (Pereira and Martinez Junior, 1986). On the other hand, in autumn and winter, which differ more obviously from spring and summer in the southern region, production is less subject to fruit fly occurrence and infestation, due to the natural reductions in the populations of this pest (Almeida et al., 2014).

Average annual temperature (Figure 4) did not present a risk for guava production, as corroborated by Almeida et al. (2014), which reported similar results for much of the central region of southern Brazil at altitudes above $1,000 \mathrm{~m}$. An average annual temperature below $19^{\circ} \mathrm{C}$ was considered as posing a risk, and the coldest area of the region had an average temperature of $20.5^{\circ} \mathrm{C}$ to $21{ }^{\circ} \mathrm{C}$.


Figure 3. Water balance for guava crop growth in municipalities of Paraná river basin 3 - adapted and organized by the authors (2019). 


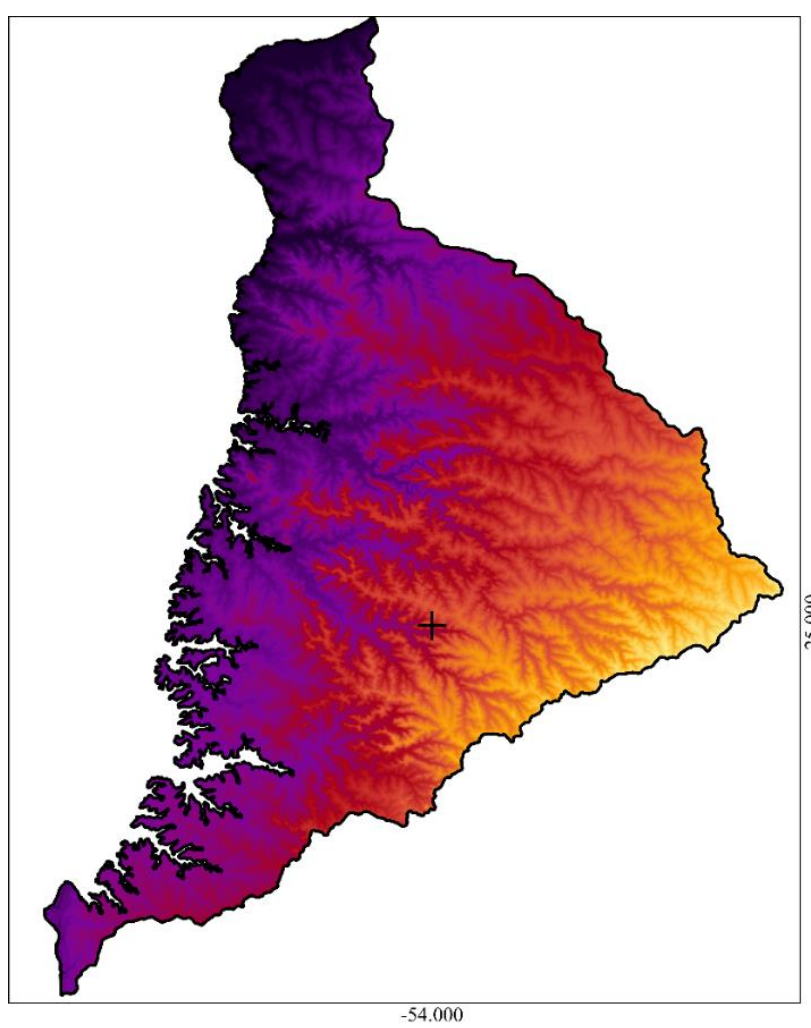

Legend

$\square$ Paraná 3 River Basin

Mean Annual Temperature

$21-21,5^{\circ} \mathrm{C}-22,5-23^{\circ} \mathrm{C}$

$21,5-22^{\circ} \mathrm{C}-23^{\circ} \mathrm{C}<$

$22-22,5^{\circ} \mathrm{C}$

Coordinate System UIM. Datum SIRGAS, $2000.22^{\circ} \mathrm{S}$ Software: ArcGis 10.5.

Data Source: Águas Paraná; ANA

Cortographic Base: IBGE, 2018.
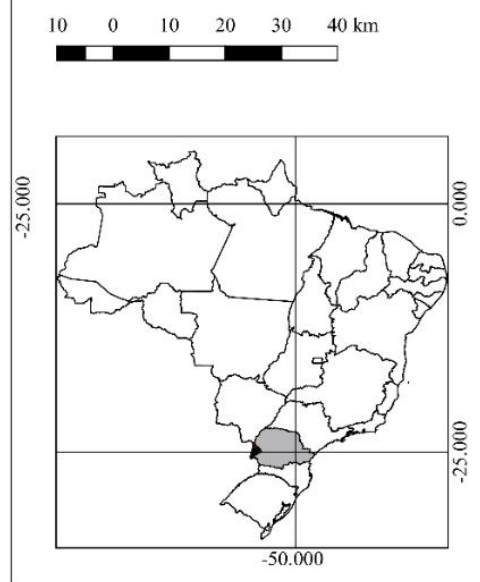

Figure 4. Average annual temperatures in Paraná river basin 3 - adapted and organized by the authors (2019).

A minimum average temperature of the coldest month of $14{ }^{\circ} \mathrm{C}$ was considered a risk due to the high probability of frost occurrence (Sentelhas et al., 1996). It was identified that this risk was not present in Paraná river basin 3, since the lowest record was in Cascavel, which is located in the most elevated area of the region, at $15.2{ }^{\circ} \mathrm{C}$ in June.

As mentioned above, the risk of frost occurrence is the main element that restricts guava production in parts of southern Brazil (Almeida, et al., 2014). In frosty conditions, guava leaves and branches may become scorched, which makes recovering the affected orchards impossible (Medina et al., 1991). The pattern of annual frost risk in the region (Figure 5) was similar to that od average temperature, with higher risks in the east and in some valleys of the central basin.

The altitude of the western region, approaching the Paraná river gutter, lends the region to guava tree cultivation, as it reduces the risk of frost to about $5 \%$ and exhibits higher average temperatures. Only the eastern area of the basin was at risk, but only for the first years of cultivation.

Figure 6 shows the final climate risk agricultural zoning map for guava. It can be observed that the regions with lower altitudes in the north, west, and south present favorable conditions for guava crop production across all analyzed variables.

Only the far east area of the basin was restricted by the occurrence of frost. However, as the risk is only relevant for the first years of cultivation, orchard protection practices can be adopted to mitigate the risk of frost and make guava production possible in the region. Even in the regions already fit for production, the risk of frost remains, so producers should avoid cultivating in valley bottoms and on slopes, and should give preference to cultivating in areas that are not too steep to facilitate the movement of cold air.

Preferably, areas of higher elevation and shallow slopes should be used, especially in the north facing areas, as the cold front has a preferential displacement in a south/southwesterly, northeasterly direction (Caldana et al., 2018; Caldana et al., 2019; Caldana e Martelócio, 2019).

As well as agroclimatic factors, other variables must also be considered. For example, areas with the possibility of severe frosts should be avoided, as this can even cause the death of young plants. In adult plants, the risk of frost damage is lower (Salazar et al., 2006). Also, areas with drainage problems should be avoided, as excessive soil moisture can inhibit plant development (Nachtigal and Migliorini, 2011). As guava is a large fruiting plant, spacings ranging from $5 \mathrm{~m}$ to $7 \mathrm{~m}$ between rows and $4 \mathrm{~m}$ to $7 \mathrm{~m}$ between plants should be used. Dense spacing negatively impacts the effectiveness of phytosanitary treatments, as well as impedes the easy navigation of machines, equipment, and people (Salazar et al., 2006; Nachtigal and Migliorini, 2011). Therefore, deciding upon production locations based on agroclimatic zoning by itself is not a guarantee of successful guava cultivation in the study region. 




Legend

$\square$ Paraná 3 River Basin

Risk of frost (\%)

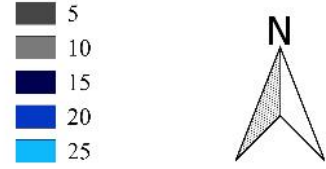

Coordinate System UTM.

Datum SIRGAS, $2000.22^{\circ} \mathrm{S}$.

Software: ArcGis 10.5.

Data Source: $\dot{\Lambda}$ guas Paraná; $\Lambda \mathrm{N} \Lambda$ :

IAPAR; INMET; SIMEPAR, 2019.

Cartographic Base: IBCII, 2018.
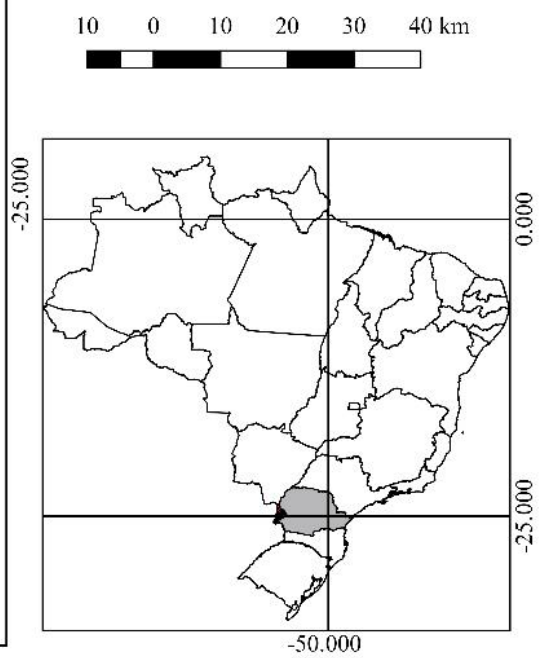

Figure 5: Frost risk in Paraná river basin 3 - adapted and organized by the authors (2019).



Figure 6. Agroclimatic risk zoning for guava (Psidium guajava) in Paraná river basin 3 - adapted and organized by the authors (2019). 
Finally, it should be noted that zoning does not eliminate risks, but only identifies areas with more favorable conditions for the development of guava. As agriculture is inherently risky, all activities are susceptible to any extreme event, which may or may not cause damage to crops. Zoning provides greater security in decision making, agricultural planning, and climate change scenarios, especially in Paraná river basin 3 .

\section{Conclusions}

- Paraná river basin 3 includes areas of low climate risk for guava cultivation.

- Rainfall and water balance were sufficient for guava crops in all scenarios evaluated.

- The most limiting factor for production in part of the basin was the occurrence of frost. However, as it is only a risk in the first years of cultivation, planting should only be restricted in areas with risks greater than $20 \%$.

- Agricultural management techniques and sustainable agricultural measures could be implemented to avoid the risk of frost. Avoiding areas of higher frost incidence is also a method of ensuring greater success in guava crop cultivation in Paraná river basin 3.

\section{Acknowledgments}

To the Itaipu Binacional, Projeto Ibitiba and Fundação Apoio a Pesquisa e Desenvolvimento do Agronegócio (FAPEAGRO) for granting scholarship to the first author.

\section{Bibliographic References}

Abdel-Rahim, I.R., Abo-Elyousr, K.A., 2017. Using of endophytic Saccharomycopsis fibuligera and thyme oil for management of gray mold rot of guava fruits. Biological control, 110, 124-131.

Adhiambo, R., Muyekho, F., Creed, I.F., Enanga, E., Shivoga, W., Trick, C.G., Obiri, J., 2019. Managing the invasion of guava trees to enhance carbon storage in tropical forests. Forest Ecology and Management, 432(15), 623-630.

Agovino, M., Casaccia, M., Ciommi, M., Ferrara, M., Marchesano, K., 2019. Agriculture, climate change and sustainability: The case of EU-28. Ecological Indicators, 105, 525-543.

Almeida, I.R., Nachtigal, J.C., Steinmetz, S., Júnior, C.R., Cuadra, S.V., 2014. Zoneamento agroclimático da cultura da goiabeira na região sul do Brasil. Pelotas, Embrapa Clima Temperado, 21 p. (Documentos, 386).

Bassoi, L.H., Silva, J.A.M., Silva, E.E.G., Ferreira, M., Maia, J.L.T., Targino, E.D.L., 2002. Informação sobre a distribuição das raízes da goiabeira para o manejo de irrigação. Embrapa Semiárido (Comunicado Técnico, 111).
Blanco, V.C.P., Burbano, O.I.I., Sarmiento-Naizaque, Z.X., Durán, J.R., 2019. Guava borer worm (Lepidoptera: Cossidae), a limiting pest in guava: biology, lifecycle and management alternatives. Heliyon, 5(2), e01252.

Caldana, N.F.S., Martelócio, A.C., 2019. Gênese, frequência e intensidade das precipitações de granizo nas Mesorregiões Centro Oriental e Sudeste Paranaense, Brasil. GeoTextos, 15(1), 205-229.

Caldana, N.F.S., Rudke, A.P., Silva, I., Nitsche, P.R., Caramori, P.H., 2019. Gênese, Impacto e a Variabilidade das Precipitações de Granizo na Mesorregião Centro-Sul Paranaense, Brasil. Caderno de Geografia, 29(56), 61-80.

Caldana, N.F.S., Yada Junior, G.M., Moura, D.A.V., Costa, A.B.F., Caramori, P.H., 2018. Ocorrências de Alagamentos, Enxurradas e Inundações e a Variabilidade Pluviométrica na Bacia Hidrográfica do Rio Iguaçu. Revista Brasileira de Climatologia, 23(2), 343-355.

Caramori, P.H., Caviglione, J.H., Wrege, M.S., Herter, F.G., Hauagge, R., Gonçalves, S.L., Citadin, I., Ricce, W.S., 2008. Zoneamento agroclimático para o pessegueiro e a nectarineira no estado do Paraná. Revista Brasileira de Fruticultura, 30(4), 1040-1044.

IPARDES, 2019. Caderno Estatístico do Estado do Paraná: Produção de Goiaba. http://www.ipardes.gov.br/imp/index.php (Accessed May 27, 2019).

Lazzarotto, C., Fornasieri, J., Comunello, E., Soriano, B., Araújo, M., Sandrini, M., 2005. Zoneamento para a fruticultura em Mato Grosso do Sul. Dourados, Embrapa Agropecuária Oeste, 39 p. (Documentos, 79).

Lem, S., Onghena, P., Verschaffel, L., Van Dooren, W., 2013. The heuristic interpretation of box plots. Learning and Instruction, 26, 22-35.

Medina, J.C., 1988. Goiaba: cultura, matéria-prima, processamento e aspectos econômicos, segunda ed. Instituto de Tecnologia de Alimentos, Campinas.

Medina, J.C., Garcia, J.L.M., Kato, K., Martin, Z.J., Vieira, L.F., Renesto, O.V., 1991. Goiaba: da cultura ao processamento e comercialização, segunda ed. Campinas, Instituto de Tecnologia de Alimentos.

Moon, P., Fu, Y., Bai, J., Plotto, A., Crane, J., Chambers, A., 2018. Assessment of fruit aroma for twenty-seven guava (Psidium guajava) accessions through three fruit developmental stages. Scientia Horticulturae, 238, 375-383.

Mueller, T.G., Pusuluri, N.B., Mathias, K.K., Cornelius, P.L., Barnhisel, R.I., Shearer, S.A., 2004. Map quality for ordinary kriging and inverse distance weighted interpolation. Soil Science Society of America Journal, 68(6), 2042-2047.

Mustafa, A., Bruwier, M., Archambeau, P., Erpicum, S., Pirotton, M., Dewals, B., Teller, J., 2018. Effects of spatial planning on future flood risks in urban environments. Journal of Environmental Management, 225, 193-204.

Nachtigal, J.C., Migliorini, L.C., 2011. Recomendações para o cultivo da goiabeira no Rio Grande do Sul. Embrapa Clima Temperado (Circular Técnica,110). 
Oliveira, A., Amaro, A.L., Pintado, M., 2018. Impact of food matrix components on nutritional and functional properties of fruit-based products. Current Opinion in Food Science, 22, 153159.

Pereira, F.M., Martinez Junior, M., 1986. Goiabas para industrialização. Jaboticabal, Legis Summa.

Rezende, F.M., Souza, A.P., Buckeridge, M.S., Furlan, C.M., 2015. Is guava phenolic metabolism influenced by elevated atmospheric CO2?. Environmental Pollution, 196(1), 483-488.

Ricce, W. S., Carvalho, S.L.C., Caramori, P.H., Auler, P.A.M., Roberto, S.R., 2014. Zoneamento agroclimático da cultura do abacaxizeiro no Estado do Paraná. Semina: Ciências Agrárias, 35(4), 2337-2345.

Salazar, D.M., Melgarejo, P., Martínez, R., Martínez, J.J., Hernández, F., Burguera, M., 2006. Phenological stages of the guava tree (Psidium guajava L.). Scientia Horticulturae, 108(2), 157-161.

Santi, A., Vicari, M.B., Pandolfo, C., Dalmago, G.A., Massignam, A.M., Pasinato, A., 2017. Impacto de cenários futuros de clima no zoneamento agroclimático do trigo na região Sul do Brasil. Agrometeoros, 25(2), 303-311.
Sentelhas, P.C., Júnior, P., Toledo, C., Sigristi, J.M.M., Kavati, R., Parodi, M.T., 1996. Freezing points of various tropical fruits. Bragantia, 55(2), 201-235.

Somboonsuke, B., Phitthayaphinant, P., Sdoodee, S., Kongmanee, C., 2018. Farmers' perceptions of impacts of climate variability on agriculture and adaptation strategies in Songkhla Lake basin. Kasetsart Journal of Social Sciences, 39(2), 277-283.

Sousa, F.M., Portela, G.L.F., Lima, M.G., Sousa, M., 2013. Zoneamento agroclimático da cultura da goiabeira no estado do Piauí, Brasil. Agropecuária Científica no Semiárido, 9(3), 8186.

Tayt'Sohn, F.C.O., Nunes, A.M.B., Pereira Junior, A.O., 2018. Assessing sugarcane expansion to ethanol production under climate change scenarios in Paranaíba river basin - Brazil. Biomass and Bioenergy, 119, 436-445.

Thornthwaite, C.W., Mather, J.R., 1955. The water balance. Centerton, New Jersey: Drexel Institute of Technology, Laboratory of Climatology (Climatology, v. 8, n. 1, 104 p.). 